\title{
Clinical cases of management and treatment of women with chemoresistant tuberculosis during pregnancy
}

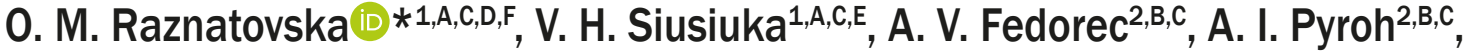 \\ H. I. Makurina ${ }^{1, E, F}$
}

${ }^{1}$ Zaporizhzhia State Medical University, Ukraine, ${ }^{2}$ Municipal Institution “Zaporizhzhia Regional TB Clinical Dispensary”, Ukraine

A - research concept and design; B - collection and/or assembly of data; C - data analysis and interpretation; D - writing the article; $\mathrm{E}$ - critical revision of the article; $\mathrm{F}$ - final approval of the article

Importance of chemoresistant tuberculosis (CRTB) is undoubted both in Ukraine and all over the world. Especially alarming fact is that together with high CRTB sickness rate among young working-age people there is the low efficiency of therapy $(55 \%)$. Data of many researchers show, that tuberculosis of pregnant women is the reason of many significant complications which make serious maternal and perinatal danger. The problem of CRTB for pregnant woman is especially dangerous because the patient should take antimycobacterial drugs of II grade for a long period and these drugs have teratogenic effect.

Purpose. Familiarization of physician-practitioners with the clinical features of the course and treatment of CRTB in women during pregnancy.

Materials and methods. 4 clinical cases of own observations of the course and treatment of CRTB in women during pregnancy were described.

Results. Among our investigations the artificial termination of pregnancy was inevitable in 3 of 4 presented clinical cases. The first patient had tubal pregnancy. The second patient: together with medical indications for artificial termination of pregnancy (multiresistant tuberculosis, unstable position of fetus), the absence of the patient's tendency for treatment of multiresistant tuberculosis and problem social factor were observed. The patient informed that pregnancy was undesirable. The third patient had polyresistant tuberculosis and generalized destructive tuberculosis in lungs and besides the artificial termination of pregnancy was also her decision. The fourth patient had medical indications for artificial termination of pregnancy (multiresistant tuberculosis, negative clinical and radiological dynamics) but she refused. With regard to refusal antimicrobial therapy was corrected and aminoglycosides were excluded. The patient was responsible as to her own health and treatment of multiresistant tuberculosis. Under complex simultaneous control of phthisiatrician, obstetrician-gynecologist and neonatologist she terminated complete course of antimicrobial therapy with successful treatment result and gave birth to healthy baby.

Conclusions. Summarizing our own observations of the pregnant patients with CRTB the following conclusion can be made: if patients with CRTB have tendency to antimicrobial therapy and desire to give birth the positive results such as CRTB treatment and delivery of healthy baby will be obtained under complex simultaneous control of phthisiatrician, obstetrician-gynecologist and neonatologist.

\section{Киінічні випадки ведення та мікування жінок, які хворі на хіміорезистентний туберкульоз під час вагітності}

\section{О. М. Разнатовська, В. Г. Сюсюка, А. В. Федорець, А. І. Пирог, Г. І. Макуріна}

Беззаперечною нині є актуальність хіміорезистентного туберкульозу (ХРТБ) в Україні й усьому світі. Особливе занепокоєння викликає те, що на тлі високого захворювання на ХРТБ молодого працездатного населення відзначають низьку ефеективність лікування (55 \%). Результати багатьох досліджень показують, що туберкульоз у вагітних жінок - причина багатьох серйозних ускладнень, які становлять серйозну материнську та перинатальну небезпеку. Особливо небезпечною єпроблема ХРТБу вагітної, оскільки пацієнтці необхідно тривало приймати антимікобактеріальні препарати II ряду, що мають значущий тератогенний вплив.

Мета роботи - ознайомлення фрахівців-практиків із клінічними особливостями перебігу та лікування ХРТБ у жінок під час вагітності.

Матеріали та методи. Описали 4 клінічні випадки власних спостережень перебігу та лікування ХРТБ у жінок під час вагітності.

Результати. 3-поміж 4 наведених клінічних випадків у 3 жінок штучне переривання вагітності було неминучим. В однієї пацієнтки була трубна вагітність. В іншої жінки на тлі медичних показань до штучного переривання вагітності (мультирезистентний туберкульоз, нестійке положення плоду) визначали відсутність схильності до лікування мультирезистентного туберкульозу та несприятливий соціальний фактор; крім того, сама пацієнтка відзначила, що вагітність небажана. У третьої пацієнтки діагностували полірезистентний туберкульоз і поширений деструктивний туберкульоз у легенях; жінка сама мала бажання штучно перервати вагітність. У четвертої пацієнтки до штучного переривання вагітності були медичні показання (мультирезистентний туберкульоз, негативна клінічно-рентгенологічна динаміка), від якого вона відмовилася. Враховуючи відмову, скорегували схему антимікобактеріальної терапії зі скасуванням аміноглікозидів. Хвора відповідально ставилася до власного здоров'я та лікування мультирезистентного туберкульозу. Під комплексним одночасним контролем фтизіатра, акушера-гінеколога та неонатолога завершила повний курс антимікобактеріальної терапії, у результаті мала успішне лікування та народила здорову дитину.
Key words: chemoresistant tuberculosis, pregnancy.

Pathologia 2020; 17 (1), 127-132

*E-mail: raxnatovskaya@ gmail.com

Киючові слова: хіміорезистентний туберкульоз, вагітність.

Патологія. 2020. T. 17, № 1(48). C. 127-132 
Висновки. Підсумовуючи власні клінічні спостереження за вагітними, які хворі на ХРТБ, можна зробити висновок: за наявності у них схильності до антимікобактеріальної терапії і бажання народити дитину, під комплексним одночасним контролем фтизіатра, акушера-гінеколога та неонатолога можна досяпти позитивних результатів - лікування ХРТБ і народження здорової дитини.

Ключевые слова: химиорезистентный туберкулез, беременность.

Патология. 2020.

T. 17, № 1(48).

C. 127-132

\section{Клинические случаи ведения и лечения женщин, больных химиорезистентным туберкулезом во время беременности}

\section{Е. Н. Разнатовская, В. Г. Сюсюка, А. В. Федорец, А. И. Пирог, Г. И. Макурина}

Бесспорна актуальность химиорезистентного туберкулеза (ХРТБ) в Украине и в мире. Особенно настораживает то, что на фоне высокой заболеваемости ХРТБ молодого трудоспособного населения отмечают низкую эффективность лечения (55 \%). Результаты многих исследований показывают, что туберкулез у беременных - причина многих серьезных осложнений, которые являются серьезной материнской и перинатальной опасностью. Особенно опасна проблема ХРТБ у беременной, поскольку пациентке необходимо длительно принимать антимикобактериальные препараты II ряда, которые имеют значительное тератогенное влияние.

Цель работы - ознакомление специалистов-практиков с клиническими особенностями течения и лечения ХРТБ у женщин во время беременности.

Материалы и методы. Описаны 4 клинических случая собственных наблюдений течения и лечения ХРТБ у женщин во время беременности.

Результаты. Из 4 представленных клинических случая у трех женщин искусственное прерывание беременности было неизбежным. У одной пациентки была трубная беременность. У другой женщины на фоне медицинских показаний к искусственному прерыванию беременности (мультирезистентный туберкулез, неустойчивое положение плода) установлено отсутствие приверженности к лечению мультирезистентного туберкулеза и неблагоприятный социальный фактор; кроме того, сама пациентка указывала, что беременность нежелательная. У третьей пациентки диагностировали полирезистентный и распространенный деструктивный туберкулез в легких, женщина сама потребовала искусственного прерывания беременности. У четвертой пациентки для проведения искусственного прерывания беременности были медицинские показания (мультирезистентный туберкулез, отрицательная клинико-рентгенологическая динамика), от которого она отказалась. Учитывая отказ, проведена коррекция схемы антимикобактериальной терапии с отменой аминогликозидов. Больная ответственно относилась к собственному здоровью и лечению мультирезистентного туберкулеза. Под комплексным одновременным контролем фртизиатра, акушера-гинеколога и неонатолога завершила полный курс антимикобактериальной терапии, результат которой - успешное лечение и рождение здорового ребенка.

Выводы. Подытоживая собственные клинические наблюдения за беременными, больными ХРТБ, можно сделать вывод: при наличии приверженности к антимикобактериальной терапии у беременных и желания родить ребенка, под комплексным одновременным контролем фтизиатра, акушера-гинеколога и неонатолога можно достичь положительных результатов - лечения ХРТБ и рождения здорового ребенка.

Importance of chemoresistant tuberculosis (CRTB) is undoubted both in Ukraine and all over the world. Especially alarming fact is that together with high CRTB sickness rate among young working-age people there is the low efficiency of therapy (55\%) [1] and majority of cases of transferring the patients to palliative therapy are observed [2]. Data of many researchers show, that tuberculosis of pregnant women is the reason of many significant complications which make serious maternal and perinatal danger $[3,4]$. The problem of CRTB for pregnant woman is especially dangerous because the patient should take antimicobacterial drugs of II grade for a long period and these drugs have teratogenic effect [1,5-7].

Today the specified definitions as to approach of pregnancy management of women with CRTB are absent in the world. In available literature sources we found only small part of works where the medical cases of own observations of such patients are described [8-11].

\section{Aim}

Familiarization of physician-practitioners with the clinical features of the course and treatment of CRTB in women during pregnancy.

\section{Materials and methods}

4 clinical cases of own observations of the course and treatment of CRTB in women during pregnancy were described. Patients had hospital treatment in pulmonary tuberculosis division No. 3 of phthisiology and pulmonology department of Zaporizhzhia State Medical University (ZSMU) in municipal institution "Zaporizhzhia Regional TB Clinical Dispensary" (ZRTBCD) within 2015-2019 years.

\section{Results of our own observations}

Patient 1: woman, 33 years old, was admitted to division of ZRTBCD with diagnosis: multiresistant tuberculosis (MRTB) (2019) of operated right lung (infiltrative). Destruction+, tuberculosis mycobacterium (MBT)+, smear $(\mathrm{S})+$, culture $(\mathrm{C})+$, resistance I (isoniazid $(\mathrm{H})$, rifampicin $(R)$, pirazinamide $(Z)$, ethambutol $(E))$, resistance II (moxifloxacin (Mfx), levofloxacin (Lfx), ofloxacin (Ofx)). Category 4 (ineffectively treated tuberculosis (IETTB), chemotherapy 1-2 grade, recurrent course). Condition after operation (2017) - resection of the upper part of right lung due to fibrotic and cavernous tuberculosis. Pulmonary failure (PF) of I level. 
General condition at the moment of hospitalization was moderately severe. During skin examination the attention was paid to available small edema of the face skin, papulopustular rash in zone of forehead, cheeks and chin. The rash became stronger in summer under the sunlight and during taking of hot drinks. The patient had been examined by dermatovenerologist who made the diagnosis: rosacea, papulopustular form. Except for dietary habits, the external therapy with use of $15 \%$ azelaic acid gel was prescribed for the patient.

The patient mentioned that she had delay of menstruation. Pregnancy test was made. It was positive. From anamnesis it was known that 4 years ago the patient had tubal pregnancy in left tube and it ended with left-side tubectomy. The patient had 4 pregnancies, 3 deliveries, 1 abortion.

Pelvic organs (PO) ultrasound examination (USE) (transabdominal method) was prescribed by physician. From USE it was known that anechogenic formation of $28 \times 26 \mathrm{~mm}$ in diameter with distinct outline and non-homogeneous structure (Fig. 1) was diagnosed in right ovary. Conclusion of PO USE: echo signs of focal mass of right ovary (according to follicular cyst type).

In 2 days control PO USE (transabdominal method) was made: anechogenic formation of $28 \times 27 \mathrm{~mm}$ in diameter with distinct outline and homogeneous structure (data as to embryo is absent) (Fig. 2.1), anechogenic formation of $17 \mathrm{~mm}$ in diameter with homogeneous structure appeared in the left ovary (Fig. 2.2). Conclusion of PO USE: echo signs of focal masses of both ovaries (according to follicular cyst type).

Control PO USE (transabdominal + vaginal methods) on the $8^{\text {th }}$ day of hospitalization: true data as to available "mistaken" gestational sac in endometrium was not revealed; in area of the left tube left ovary the anechogenic formation of $27 \mathrm{~mm}$ in diameter with distinct outline was diagnosed, near to which the anechogenic formation up to $23 \mathrm{~mm}$ with hyperechogenic inclusion up to $8 \mathrm{~mm}$ in diameter (embryo?) was diagnosed, obvious painfulness was available during compression with sensor. Conclusion of PO USE: echo signs of focal masses of the left ovary, left tubal pregnancy.

The patient was consulted by gynecologist. Provisional diagnosis: tubal pregnancy (on the left side).

On the $9^{\text {th }}$ day of hospitalization the recurrent PO USE (vaginal method) was made: close to the right ovary the formation of $25 \times 21 \mathrm{~mm}$ with distinct smooth outline, hyperechogenic walls up to $5 \mathrm{~mm}$ - gestational sac of $13 \times 11 \mathrm{~mm}$, embryo of 7-8 mm, heartbeat + and yolk sac up to $2.5 \mathrm{~mm}$ were diagnosed. Structure of the left ovary is presented by anechogenic formation up to $23 \times 22 \mathrm{~mm}$ in diameter with distinct smooth outline, insufficiently homogenous structure close to follicle up to $15 \mathrm{~mm}$. Conclusion of PO USE: echo signs of progressing extrauterine pregnancy (on the right side) of 5-6 weeks; cyst formation of the left ovary.

After getting results of the last PO USE the patient was operated in Zaporizhzhia Regional Clinical Hospital: laparatomy, right-side tubectomy. Post-operative period passed without peculiarities. In 4 days the patient was transferred to ZRTBCD for proceeding with antimicrobial therapy (AMBT) of MRTB according to scheme of category 4 with consideration of medical sensibility test

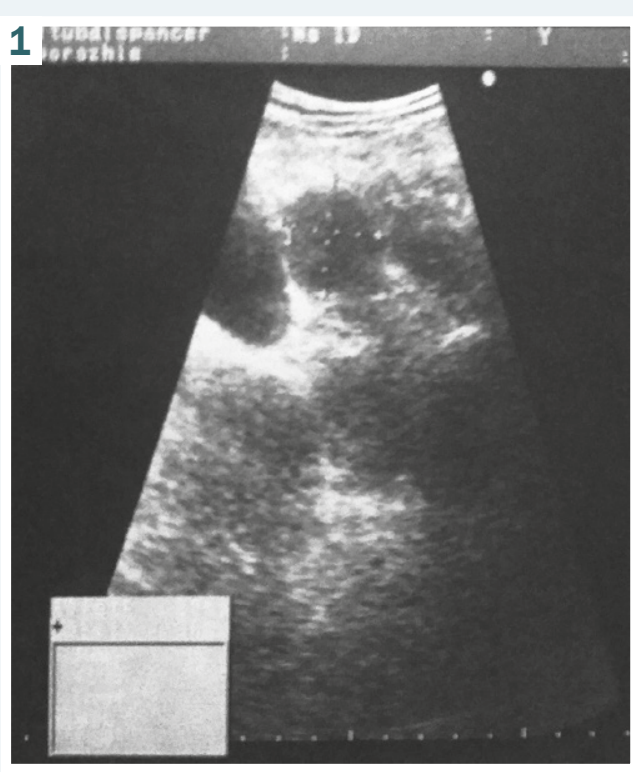

Fig. 1. PO USE: the right ovary.

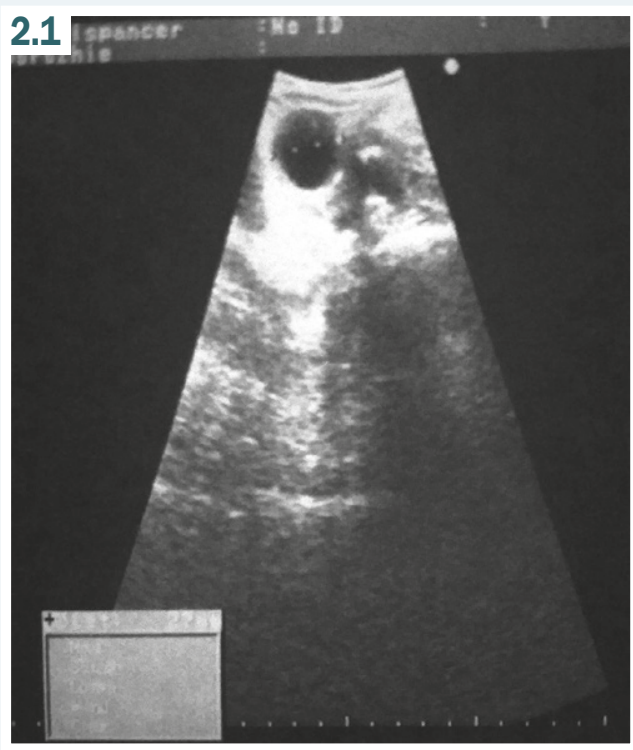

Fig. 2. PO USE 2.1: the right ovary, 2.2: the left ovary.

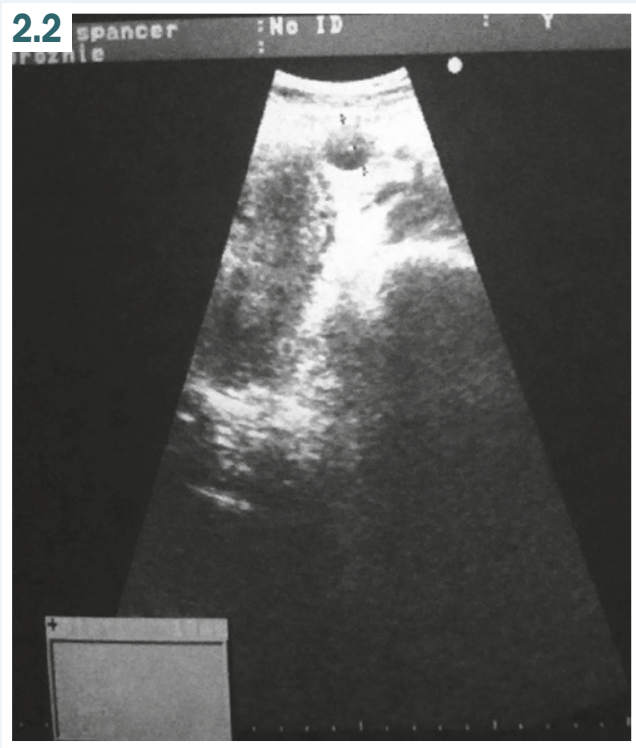


(MST). But in 3 month the patient left hospital without permission due to this fact she was discharged from hospital.

Patient 2: woman, 22 years old. She had tuberculosis for one year. At first it was revealed during preventative examination in maternity hospital. Then she had ambulatory treatment course of firstly diagnosed tuberculosis (FDTB) under scheme of category I. But during control examination after termination of maintaining phase MBT was revealed in sputum. Based on this fact the patient was transferred to category 2 for proceeding with therapy due to IETTB. But the patient didn't have tendency for treatment thus she started treatment only in 3 months. Within this period the results of molecular genetic test (MG), sputum culture for liquid medium: MBT+, MG+, rifampicin (Rif)+, resistance I (HRZ, streptomycin (S)) were obtained. Considering obtained data the diagnosis was made: MRTB of the upper part of the left lung (infiltrative). Destruction-, MBT + M- MG+ Rif+ C+, resistance I (HRZS). Category 4 (IETTB).

During 2 months the patient was in waiting list till formation of tendency for treatment. In 2 months the patient willingly came for hospitalization treatment in regional antituberculosis clinical dispensary where AMBT according to category 4 with consideration of MST.

In 2 weeks the patient informed that she was obviously pregnant and pregnancy is undesirable. She was consulted by gynecologist. PO USE was made: in the uterine cavity one fetus id revealed; heart rate $(\mathrm{HR})$ is 140 beats per minute, pregnancy term is 17 weeks. Due to this fact correction of AMBT was made. Aminoglycosides were excluded from the scheme. The patient was transferred to ZRTBCD for determination of approach of further patient management.

The patient condition at the moment of hospitalization in ZRTBCD was satisfactory. From anamnesis it was known that social state of the patient is problem (she lived in private house with 3 children, mother and 3 sisters). It was her fifth pregnancy.

The patient was consulted by gynecologist. PO USE was made: in the uterine cavity one fetus was revealed; heart rate $(\mathrm{HR})$ was 140 beats per minute, pregnancy term was 18 weeks, fetus position was unstable. In one week after treatment in ZRTBCD there was made decision of artificial abortion for medical reasons (MRTB, unstable position of fetus) + undesirable pregnancy, absence of the patient's tendency for treatment of MRTB and problem social factor. For this purpose the patient was transferred to Regional Perinatal Center (RPC).

In 3 days the patient had been transferred again to ZRTBCD where after correction of AMBT she was transferred to district tuberculosis dispensary according to the residence registration in order to proceed with AMBT under the scheme of category 4 with consideration of MST.

Patient 3: woman, 24 years old. Earlier she didn't have tuberculosis. But 1.5 years earlier she had contact with tubercular cohabitant.

Tuberculosis was revealed while visiting the doctor with complaints on long-term cough, subfebrile temperature in the evening during 2 weeks, weight loss for $4 \mathrm{~kg}$ within last month, pain in right scapula area. After additional examination of the patient the changes of thoracic organs (TO) on X-ray film were revealed: in the right lung the cavity of destruction of $4 \mathrm{~cm}$ in diameter associated with focal and small focus shadows, fibrosis were revealed; the right root of lung and cupula of diaphragm were deformed. MBT was revealed in sputum. Based on this fact the patient was transferred to hospital treatment in ZRTBCD.

The patient condition at the moment of hospitalization in ZRTBCD was satisfactory. Due to the face skin rash the patient was consulted by dermatologist.

During examination the hyperpigmented marks with distinct outlines and diameter up to $4-5 \mathrm{~cm}$ looking like geographical map were revealed on the skin of temporal region, forehead and upper lip. Hyperpigmentation was more obvious during examination under ultraviolet Wood's lamp. Diagnosis of the patient was determined: chloasma. Due to this fact the external therapy with use of azelaic acid was recommended.

By means of MG-method MBT (MBT+ MG+ Rif+) resistant to rifampicin were revealed in sputum. In result the diagnosis was determined: tuberculosis resistant to rifampicin (RifTB), infiltrative tuberculosis of the right lung. Destruction+, MBT+ MG+ Rif+. Category 4 (FDTB).

Analysis of blood for antibodies (AB) against human immunodeficiency virus (HIV) was negative. AMBT was prescribed under category 4 with consideration of MST data.

The patient mentioned that she had delay of menstruation during 1 month. The patient was examined by gynecologist: pregnancy test and PO USE were prescribed.

Pregnancy test was positive.

During PO USE (transabdominal method): the anechogenic focus up to $28 \mathrm{~mm}$ (gestational sac) containing one embryo was diagnosed. Conclusion of PO USE: echo signs of pregnancy of 7-8 weeks. From anamnesis: pregnancy I.

During sputum culture for liquid medium MBT resistance to HESZ was revealed. Based on this factor the diagnosis was determined: polyresistant tuberculosis (PRTB), infiltrative tuberculosis of the right lung. Destruction+, MBT+ M+ MG+ Rif+. Category 4 (FDTB). Correction of AMBT with consideration of MST data was made.

According to medical indications (PRTB, generalized destructive tuberculosis in lungs) and at the discretion of patient the artificial termination of pregnancy at the term of 9 weeks was made. Post-operative period passed without peculiarities.

The patient proceeded with AMBT according to the scheme of category 4 with consideration of MST data. The patient was in hospital during whole intensive phase of treatment (6 months). In result the bacterioexcretion stopped in 2 months. During transfer to maintaining phase of AMBT clinical and radiological dynamics was positive.

Patient 4: woman, 23 years old. Earlier she didn't have tuberculosis. Possible contact with tubercular patient was denied. During preventative examination focal lung lesions were revealed in the upper part of the right lung. After additional examination MBT was revealed in sputum. Then the patient was transferred to ZRTBCD for hospital treatment. In ZRTBCD she was additionally examined. The right lung destruction of $0.8 \mathrm{~cm}$ in diameter was revealed in tomographic image. 
There was determined diagnosis: FDTB of the upper part of the right lung (infiltrative). Destruction+, MBT+ $\mathrm{M}+$. Category 1. The patient started course of AMBT according to scheme of category $\mathrm{I}$.

In 3 weeks after obtaining the result of MST which indicated available resistivity of MBT to HRS the patient was presented to MRTB-council. Diagnosis was determined: MRTB of the upper part of the right lung (infiltrative). Destruction+, MBT+ M+ MG0 C+, resistivity I (HRS). Category 4 (FDTB). Course of AMBT according to scheme of category 4 with consideration of MST data was prescribed.

In 2 months of hospitalization the patient's X-ray picture showed negative dynamics: increase of size of focus in the upper part of the right lung and destruction dimensions in focus from $0.8 \mathrm{~cm}$ up to $2 \mathrm{~cm}$ in diameter.

In 6 months the patient informed doctor that she had visited her local gynecologist and possibly she was pregnant (9-10 weeks). Then the patient was examined by gynecologist of ZRTBCD: pregnancy of 10 weeks and bacterial vaginosis. PO USE was prescribed.

PO USE (transabdominal method): anechogenic focus up to $50 \mathrm{~mm}$ (gestational sac) contains one embryo. Conclusion of PO USE: echo signs of pregnancy of 10-11 weeks. From anamnesis: pregnancy I.

Considering medical indications (MRTB, negative clinical and radiological dynamics) the patient was proposed to make artificial termination of pregnancy. But she refused. Due to refusal AMBT was corrected and aminoglycosides were excluded. The patient was hospitalized within intensive phase of AMBT (8 months). During this period the positive clinical and radiological dynamics was observed: bacterioexcretion stopped in 4 months, destruction was healed.

The patient was discharged for ambulatory treatment and further treatment in maintaining phase.

The patient was responsible as to her own health and treatment of MRTB. According to the information of her local phthisiatrician she gave birth to healthy baby and finished complete course of AMBT with successful treatment result.

\section{Discussion}

Having made analysis of literature sources we found that recommendations as to management of pregnant women with CRTB are rather contradictory. With regard to unsuccessful results of treatment and delivery of the patients with MBTB A. Dudnyk and O. Pavel'chuk [7] indicate necessity of artificial termination of pregnancy term of which makes from 12 to 22 weeks [12]. However the part of researchers recommends to perform AMBT of pregnant women with CRTB [8-12] without abortion. Besides the attention is drawn to the fact that management of such patients should be under complex simultaneous control of such specialists as phthisiatrician, obstetrician-gynecologist and neonatologist. Treatment course of CRTB should be complete and appropriate. Moreover all these researchers indicate safety and efficiency of AMBT during pregnancy. According to recommendations of World Health Organization [1] such drugs as amikacin, streptomycin, prothionamide and ethionamide are ex- cluded from treatment scheme due to their teratogenic effect on fetus.

Among our investigations the artificial termination of pregnancy was inevitable in 3 of 4 presented clinical cases. The first patient had tubal pregnancy. The second patient: together with medical indications for artificial termination of pregnancy (MRTB, unstable position of fetus), the absence of the patient's tendency for treatment of MRTB and problem social factor were observed. The patient informed that pregnancy was undesirable. The third patient had PRTB and generalized destructive tuberculosis in lungs and besides the artificial termination of pregnancy was also her decision. The fourth patient had medical indications for artificial termination of pregnancy (MRTB, negative clinical and radiological dynamics) but she refused. With regard to refusal AMBT was corrected and aminoglycosides were excluded. The patient was responsible as to her own health and treatment of MRTB. Under complex simultaneous control by phthisiatrician, obstetrician-gynecologist and neonatologist she terminated complete course of AMBT with successful treatment result and gave birth to healthy baby.

\section{Conclusions}

Summarizing our own observations of the pregnant patients with CRTB the following conclusion can be made: if patients with CRTB have tendency to AMBT and desire to give birth the positive results such as CRTB treatment and delivery of healthy baby will be obtained under complex simultaneous control by phthisiatrician, obstetrician-gynecologist and neonatologist.

Prospects for further research. Further observations over the pregnant women with CRTB including patients with co-infection CRTB/HIV.

Conflicts of interest: authors have no conflict of interest to declare. Конфлікт інтересів: віАсутній.

Надійшла Ао редакції / Received: 04.07.2019

Після Аоопрацювання / Revised: 30.10.2019

Прийнято АО Аруку / Accepted: 27.02.2020

Information about authors:

Raznatovska 0. M., MD, PhD, DSc, Professor, Head

of the Department of Phthisiology and Pulmonology, Zaporizhzhia

State Medical University, Ukraine.

ORCID ID: 0000-0003-2252-9063

Siusiuka V. H., MD, PhD, DSc, Associate Professor

of the Department of Obstetrics and Gynecology, Zaporizhzhia

State Medical University, Ukraine.

Fedorec A. V., MD, Phthisiatrician of Pulmonary Tuberculosis

Department No. 3, Municipal Institution “Zaporizhzhia Regional

TB Clinical Dispensary", Ukraine.

Pyroh A. I., Deputy Chief Medical Officer, Municipal Institution

“Zaporizhzhia Regional TB Clinical Dispensary”, Ukraine.

Makurina H. I., MD, PhD, DSc, Associate Professor, Head

of the Department of Dermatovenerology and Cosmetology with the Course of Dermatovenerology and Aesthetic Medicine of Postgraduate Education Faculty, Zaporizhzhia State Medical University, Ukraine.

\section{Відомості про авторів:}

Разнатовська О. М., А-р меА. наук, професор, зав. каф. фтизіатрії і пульмонології, Запорізький Аержавний меАичний університет, Україна. 
Сюсюка В. Г., А-р меА. наук, Аоцент каф. акушерства і гінекології, Запорізький державний меАичний університет, Україна.

Федорець А. В., лікар-фтизіатр відАілення мегеневого туберкульозу № 3, КУ «Запорізький обласний протитуберкульозний клінічний Аиспансер", Україна.

Пирог А. І., заступник головного лікаря з медичної частини, КУ «Запорізький обласний протитуберкульозний клінічний Аиспансер", Україна.

Макуріна Г. І., А-р меА. наук, Аоцент,

зав. каф. Аерматовенерології та косметології з курсом Аерматовенерології і естетичної меАицини ФПО, Запорізький Аержавний медичний університет, Україна.

\section{Сведения об авторах:}

Разнатовская Е. Н., А-р меА. наук, профессор, зав. каф. фтизиатрии и пульмонологии, Запорожский государственный медицинский университет, Украина. Сюсюка В. Г., А-р меА. наук, Аоцент каф. акушерства и гинекологии, Запорожский государственный медицинский университет, Украина.

Федорец А. В., врач-фтизиатр отАеления мегочного туберкулеза № 3, КУ «Запорожский областной противотуберкулезный клинический диспансер", Украина.

Пирог А. И., заместитель главного врача по медицинской части, КУ «Запорожский областной противотуберкулезный клинический диспансер", Украина.

Макурина Г. И., А-р меА. наук, Аоцент,

зав. каф. Аерматовенерологии и косметологии с курсом Аерматовенерологии и эстетической меАицины ФПО, Запорожский государственный медицинский университет, Украина.

\section{References}

[1] World Health Organization. (2019). Global tuberculosis report 2019. http://www10.who.int/tb/publications/global_report/en/

[2] Raznatovska, O. M., \& Khudyakov, G. V. (2018). Factors of chemoresistant pulmonary tuberculosis progression in patients receiving palliative treatment. Zaporozhye medical journal, 20(3), 388-391. https://doi. org/10.14739/2310-1210. 2018.3.130829

[3] Chopra, S., Siwatch, S., Aggarwal, N., Sikka, P., \& Suri, V. (2017) Pregnancy outcomes in women with tuberculosis: a 10-year experience from an Indian tertiary care hospital. Tropical Doctor, 47(2), 104-109. https://doi.org/10.1177/0049475516665765

[4] El-Messidi, A., Czuzoj-Shulman, N., Spence, A. R., \& Abenhaim, H. A. (2016). Medical and obstetric outcomes among pregnant women with tuberculosis: a population-based study of 7,8 million births. American Journal of Obstetrics and Gynecology, 215(6), 797-799. https://doi. org/10.1016/j.ajog.2016.08.009

[5] Rai, D. (2017). Tuberculosis in pregnancy. Eastern Journal of Medical Sciences, 1(2), 42-45. https://atharvapub.net/EJMS/article/view/300

[6] Prasad, R., Gupta, N., Singh, A., \& Gupta, P. (2015). Multidrug-resistant and extensively drug-resistant tuberculosis (M/XDR-TB): management in special situations. International Journal of Medical Science and Public Health, 4(12), 1626-1633. https://doi.org/10.5455/ ijmsph.2015.01082015364

[7] Dudnyk, A., \& Pavel'chuk, O. (2016). Multidrug-resistant tuberculosis in pregnant women: Treatment and birth outcomes. European Respiratory Journal, 48. https://doi.org/10.1183/13993003.congress-2016.PA1912

[8] Ünlü, M., Cimen, P., Arı, G., \& Sevket, Dereli M. (2015). A Successfully Treated Severe Case of Extensively Drug-Resistant Tuberculosis During Pregnancy. Respiratory Case Reports, 4(1), 67-71. https://doi. org/10.5505/respircase.2015.32932

[9] Tabarsi, P., Moradi, A., Baghaei, P., Marjani, M., Shamaei, M., Mansouri, N., Chitsaz, E., Farnia, P., Mansouri, D., Masjedi, M., \& Velayati, A. (2011). Standardised second-line treatment of multidrug-resistant tuberculosis during pregnancy. International Journal of Tuberculosis and Lung Disease, 15(4), 547-550. https://doi.org/10.5588/ijtld.10.0140

[10] Rohilla, M., Joshi, B., Jain, V., Kalra, J., \& Prasad, G. R. V. (2016). Multidrug-Resistant Tuberculosis during Pregnancy: Two Case Reports and Review of the Literature. Case Reports in Obstetrics and Gynecology, 2016, Article ID 1536281. https://doi. org/10.1155/2016/1536281

[11] Laniado-Laborin, R., Carrera-Lopez, K., \& Hernandez-Perez, A. (2018). Unexpected Pregnancy during Treatment of Multidrug-resistant Tuberculosis. Turkish Thoracic Journal, 19(4), 226-227. https://doi. org/10.5152/TurkThoracJ.2018.17062
[12] Cabinet of Ministers of Ukraine. (2006, February 15). Pro realizatsiiu statti 281 Tsyvilnoho kodeksu Ukrainy 15.02.2006 No. 144 [On the implementation of Article 281 of the Civil Code of Ukraine (No. 144)]. [in Ukrainian]. https://zakon.rada.gov.ua/laws/show/144-2006-\%D0\%BF?lang=en 